\title{
Genetic evidence for extensive cryptic speciation in the subtidal sponge Plakina trilopha (Porifera: Demospongiae: Homoscleromorpha) from the Western Mediterranean
}

\author{
Guilherme Muricy ${ }^{1,2}$, Antonio M. Solé-Cava ${ }^{3,4}$, John P. Thorpe ${ }^{4}$, \\ Nicole Boury-Esnault ${ }^{2}$
${ }^{1}$ Departamento de Bioquímica, Instituto de Quimica, Universidade Federal do Rio de Janeiro, Cidade Universitária, C.T., bloco A, $5^{\circ}$ andar, 21941 Rio de Janeiro, RJ, Brazil
${ }^{2}$ Centre d'Océanologie de Marseille, Université de la Méditerranée, CNRS URA-41, Station Marine d'Endoume, Rue de la Batterie des Lions, F-13007 Marseille, France
${ }^{3}$ Departamento de Genética, Institulo de Biologia, Universidade Federal do Rio de Janeiro, Cidade Universitária, C.C.S, bloco A, 21941 Rio de Janeiro, RJ, Brazil
${ }^{4}$ Department of Environmental and Evolutionary Biology, University of Liverpool, Port Erin Marine Laboratory, \\ Port Erin, Isle of Man IM9 6JA, United Kingdom
}

\begin{abstract}
To date, only 3 species of the sponge genus Plakina Schulze have been identified in the Mediterranean: P. monolopha, P. dilopha and P. trilopha. These species are distinguished on the basis of the presence of a particular spicule type (lophocalthrops) with 1, 2 and 3 lophate actines, respectively. In a survey of plakinids on vertical walls and submarine caves in the Mediterranean around Marseilles, France, we found 4 different morphotypes of what would normally be identified as $P$ trilopha (i.e. with trilophose calthrops). However, slight but consistent differences in morphological characters and ecology led us to doubt the conspecificity of these morphotypes. Genetic divergence and reproductive isolation between morphotypes were investigated through allozyme electrophoresis. It was found that all 4 morphotypes were reproductively isolated from each other, with diagnostic loci between any pair of morphotypes compared. Genetic identities between morphotypes ranged from 0.49 to 0.83 . The genetic differences found between the morphotypes indicate that these should not be considered conspecific. Once species boundaries were delimited by genetic data, diagnostic morphological characters for each species could be found.
\end{abstract}

KEY WORDS: Porifera-Sponge - Plakina trilopha Allozymes Cryptic speciation - Genetics

\section{INTRODUCTION}

Sponges (Phylum Porifera) present great difficulties for systematists, and their classification is still subject to disputes covering all taxonomic levels from subclass to species. At the species level problems are the morphological plasticity and polymorphism of many species, allied with difficulties in conducting breeding experiments. A paucity of useful (diagnostic), easily observed characters and inadequate descriptions are also frequent problems.
It is also difficult to avoid subjectivity in descriptions, a problem that arises from the nature of sponges, their great morphological plasticity, variable organization and shortage of reliable morphological features. As a consequence, systematists try to objectively define characters such as consistency, subtle colour variations or shape. Subjectivity in taxonomic decisions can be reduced either by looking for a greater number of characters or by using alternative more objective methods.

Long standing problems in sponge systematics are increasingly being addressed through means of inves- 
tigation of biochemical, cytological, reproductive and ecological characters (see e.g. Van Soest et al. 1994), which add phylogenetic information to the classical morphological characters. Allozyme electrophoresis has been widely used to investigate the genetic structure of natural populations in a wide range of plant and animal species (reviewed by e.g. Ryman \& Utter 1987 , Avise 1994, Thorpe \& Solé-Cava 1994). This method is particularly useful in solving taxonomic problems and in distinguishing species and quantifying divergence between populations or species in a wide range of marine invertebrates, including sponges (Solé-Cava \& Thorpe 1986, 1994, Solé-Cava et al. 1991a, b, Bavestrelo \& Sarà 1992, Klautau et al. 1994).

The present work is concerned with a problem of species boundaries in the sponge genus Plakina Schulze, 1880, of the family Plakinidae Schulze, 1880 , which in turn is considered the only family of the subclass Homoscleromorpha Lévi, 1973 (Solé-Cava et al. 1992, Diaz \& Van Soest 1994). Apart from dealing with a taxonomic problem this case also illustrates some general difficulties in sponge taxonomy.

The genus Plakina is defined in a recent revision (Diaz \& Van Soest 1994) as 'thinly to massively encrusting Plakinidae with a spiculation of diods, triods and calthrops, and with lophocalthrops with 1, 2, 3 or 4 lophate rays. Eurypylous choanocyte chambers usually with a radial arrangement of chambers around a central excurrent canal were found in samples studied histologically ( $P$. elisa, $P$, monolopha). Lophocalthrops are highly concentrated at the sponge surface. Occurrence: cosmopolitan'. Schulze (1880) erected the family Plakinidae and described 3 Mediterranean species of Plakina: P. monolopha, P. dilopha and P. trilopha, characterized by the presence of respectively 1,2 or 3 lophate rays in the Iophocalthrops (one of the spicule types). Since then several authors have reported the widespread occurrence of $P$. monolopha and $P$. trilopha in the Mediterranean and in many other seas (e.g. Topsent 1895, 1917, de Laubenfels 1951, Thomas 1970 , Vacelet \& Vasseur 1971, Uriz \& Bibiloni 1984, Lévi \& Lévi 1989) and both species are considered cosmopolitan. However, since Schulze (1880) no other Plakina species has been described from the Mediterranean. Most authors reported some variation in spicule shape and size in $P$. trilopha, but considered this to be intraspecific.

In a survey of homoscleromorph sponge species encrusting submarine caves and vertical walls in the Western Mediterranean around Marseilles (Southern France) we found several different morphotypes of Plakina, all of which were preliminarily identified as P. trilopha as they have trilophose calthrops. More detailed studies however showed slight differences in colour, shape, size and spiculation between the popu- lations of the different morphotypes, and led us to question the conspecificity of these populations. In the present study allozyme electrophoresis is used to investigate gene flow between 4 different morphotypes of ' $P$. trilopha' to ascertain whether the 4 morphotypes could be viewed as part of a plastic, polymorphic species possibly adapting to different habitats (ecotypes), or as separate independently evolving biological species.

\section{MATERIAL AND METHODS}

Samples of 4 different morphs (morphotypes A to D) of Plakina trilopha Schulze were collected during July and August 1993 from shallow submarine caves and vertical rock walls in the Mediterranean Sea near Marseilles. Specimens of $P$. monolopha Schulze were also collected to provicie a taxonumic outgroup. The 2 collection sites furthest apart were about $30 \mathrm{~km}$ from each other. All samples were obtained by SCUBA diving at depths of 5 to $25 \mathrm{~m}$ and frozen in liquid nitrogen until required. The main charactcristics of each morphotype studied and their collection sites are summarized in Table 1. Difficulties involved in the collection of small sponges in cryptic environments and problems in allozyme resolution limited the number of samples analyzed to 2 to 8 specimens per morphotype (Table 1).

In the laboratory tissue samples were analyzed by horizontal $12.5 \%$ starch gel electrophoresis using methods previously described (Solé-Cava \& Thorpe 1986). The buffer systems used throughout were Tris-Citrate, $\mathrm{pH} 8.0$ and LiOH-Borate, pH 8.3 (Ward \& Beardmore 1977). Gels were stained for 20 different enzymes, but interpretable and reproducible results for all the morphotypes studied could only be obtained for 5 enzymes (coded by 11 loci). Enzyme staining methods and nomenclature follow standard procedures (Harris \& Hopkinson 1978, Richardson et al. 1986). The enzymes studied and their abbreviations were: Hexokinase, HK, E.C.2.7.1.1; Pro-Phe Peptidase, PEP, E.C.3.4.11.1; Phosphoglucose isomerase, PGI, E.C.5.3.1.9; NADH Diaphorase, DIA, E.C.1.6.2.2; and alpha-esterases, EST, E.C.3.1.1.1. Clone-mates could be excluded from the analysis by pooling together all individuals with identical allozyme pattern and counting them as one (Solé-Cava \& Thorpe 1986). That was not necessary in this study, however, since no 2 individuals in our sample had the same genotype over the 11 loci analyzed. Genotype frequencies were used to estimate gene frequencies, from which levels of genetic variation and unbiased genetic identities and distances (Nei 1978) were calculated, using the program BIOSYS-1 (Swofford \& Selander 1981). The genetic distance indices were used to produce a neighbor-joining 
Table 1 Morphological and ecological comparison of the 4 morphotypes (A to D) of Plakina studied. Unless otherwise noted, measurements given for spicule sizes are in $\mu \mathrm{m}$ : length range (mean $\pm \mathrm{SD}$ ) $\times$ width range (number of spicules measured)

\begin{tabular}{|c|c|c|c|c|}
\hline \multicolumn{5}{|c|}{ Morphotype } \\
\hline & A & B & $\mathrm{C}$ & $\mathrm{D}$ \\
\hline Specimens studied & 8 & 3 & 3 & 2 \\
\hline Colour & Yellow & White & White/cream & White \\
\hline Form & Large spreading & Large spreading & Small discoidal & Small discoidal \\
\hline Lobes (mm) & $5-10$ & $5-10$ & $0.5-2.0$ & $0.5-2.0$ \\
\hline Surface & Smooth & Smooth & Microlobate & Smooth \\
\hline Consistency & Firm & Firm & Delicate & Delicate \\
\hline \multicolumn{5}{|l|}{ Spicules: } \\
\hline Diods & $43-100(67.3 \pm 14) \times 1-3(53)$ & $40-88(74.5 \pm 11.4) \times 1-3(25)$ & $60-75(69.7 \pm 5.7) \times 2-5(31)$ & $50-75(65.1 \pm 8.3) \times 2-4(25)$ \\
\hline Triods ${ }^{a}$ & $15-37(29.2 \pm 6.5) \times 1-3(54)$ & $12-33(26.5 \pm 7) \times 1-3(24)$ & $18-30(26.7 \pm 5.7) \times 2-4(33)$ & $18-30(22.8 \pm 4.3) \times 2-4(29)$ \\
\hline Calthrops $^{d}$ & $16-38(23.1 \pm 4.2) \times 1-3(39)$ & $10-35(23 \pm 8.5) \times 1-3(19)$ & $20-32(26.2 \pm 4.9) \times 2-4(28)$ & $18-25(21.2 \pm 2.6) \times 2-4(17)$ \\
\hline \multicolumn{5}{|l|}{ Lophocalthrops } \\
\hline Monolophose & $22-38(27.9 \pm 8.2) \times 1-3(13)$ & $20-30(26.2 \pm 4.4) \times 1-3(11)$ & $30-35(31.7 \pm 2.1) \times 2-5(8)$ & - \\
\hline Dilophose & $30-35(25.3 \pm 3.5) \times 1-3(9)$ & $20-35(22.5 \pm 3.3) \times 1-3(8)$ & $27-35(28.9 \pm 4.8) \times 2-4(28)$ & $19-36(28.8 \pm 5.2) \times 2-5(21)$ \\
\hline Trilophose & $19-32(24.7 \pm 4.3) \times 1-3(43)$ & $16-27(20.9 \pm 5.1) \times 1-3(25)$ & $15-20(20.8 \pm 3.3) \times 2-4(25)$ & $22-28(24.4 \pm 3.4) \times 2-4(19)$ \\
\hline Tetralophose & $10-25(17.7 \pm 4.3) \times 1-3(29)$ & $10-25(17.1 \pm 2.9) \times 1-3(18)$ & $12-20(16.3 \pm 2.7) \times 2-4(11)$ & - \\
\hline Malformations & Abundant & Common & Rare & Common \\
\hline Spination & Abundant & Common & Rare & Rare \\
\hline Habitat & Semi-obscure cave & Semi-obscure cave & Semi-obscure cave & Overhanging \& vertical rocks \\
\hline Collection sites & 3PP cave & 3PP and Jarre cave & Endoume cave & Grand Congloue \\
\hline Depth $(\mathrm{m})$ & $12-15$ & $12-15$ & $3-5$ & 15 \\
\hline Size of 1 actine & & & & \\
\hline
\end{tabular}

tree, using Plakina monolopha as an outgroup, with the program MEGA (Kumar et al. 1993). This clustering algorithm was preferred over the more commonly used unweighted pair-group mean algorithm (UPGMA) because it is less sensitive to variation in evolutionary rates between branches (Saitou \& Nei 1987).

\section{RESULTS}

Allele frequency data for the 11 loci for which all 5 samples of Plakina were scored are summarized in Table 2. From the data it is clear that whilst there is the expected clear genetic differentiation between $P$. monolopha and the samples of P. trilopha, there is also unexpectedly high divergence between the 4 morphotypes of P. trilopha.

Of the 11 loci typed in the 4 Plakina trilopha morphotypes, only 1 (Est-4), which was monomorphic, was identical in all morphotypes. The remaining 10 loci were polymorphic each with between 2 and 4 alleles. Three of these loci (Est-3; Dia-2; Pep-2) provide no evidence of a significant difference $(p<0.05)$ between morphotypes. However the remaining 7 loci all show significant heterogeneity between morphotypes, with various of these being fixed for different alleles at some of these loci. At all loci there was at least 1 allele shared by 2 or more populations. However from Table 2 it appears that each morphotype can be distin- guished from each other morphotype by 2 to 6 diagnostic loci (sensu Ayala 1983).

The values for Nei's (1978) unbiased genetic identities between populations (Table 3, Fig. 1) ranged from 0.49 between morphotypes $\mathrm{A}$ and $\mathrm{C}$ to 0.83 between $\mathrm{A}$ and $B$. Although the genetic distance between the last 2 morphotypes is close to the range expected of conspecific populations (above about 0.85 ; Thorpe 1982 , 1983, Nei 1987), the other lower values are well within the range usual for congeneric species (about 0.35 to 0.85; Thorpe 1982, 1983, Nei 1987).

\section{DISCUSSION}

The results of enzyme electrophoresis indicate that all 4 morphotypes of Plakina studied are genetically differentiated. In the case of the sympatric morphs $A$ and $B$ this is a clear indication that they belong to different species. Between allopatric populations however a certain amount of genetic differentiation is to be expected even if the populations are conspecific (see e.g. Thorpe \& Solé-Cava 1994). So far, morphotypes A, $\mathrm{C}$ and $\mathrm{D}$ are known only from different sites in the same general area (A and C from caves, D from a vertical rock wall). Although all collection sites were located within only $30 \mathrm{~km}$ of coastline, the restricted water circulation in caves is expected to severely reduce transport of gametes and larvae between them. 
Table 2. Plakina trilopha. Allele frequencies for 11 loci in the 4 morphotypes and the outgroup, $P$. monolopha, from the Western Mediterranean. Number of alleles analyzed per locus $(N)$ is given in italics. nd: not determined

\begin{tabular}{|c|c|c|c|c|c|c|}
\hline Locus & Allele & A & B & $\mathrm{C}$ & $\mathrm{D}$ & P. monolopha \\
\hline \multirow[t]{3}{*}{ Dia-1 } & A & 1.00 & 0.00 & nd & 1.00 & 1.00 \\
\hline & B & 0.00 & 1.00 & nd & 0.00 & 0.00 \\
\hline & $(\mathrm{N})$ & 16 & 6 & - & 2 & 4 \\
\hline \multirow[t]{4}{*}{ Dia-2 } & A & 0.00 & 0.00 & 0.17 & 0.00 & 0.00 \\
\hline & B & 1.00 & 1.00 & 0.83 & 1.00 & 0.00 \\
\hline & $\mathrm{C}$ & 0.00 & 0.00 & 0.00 & 0.00 & 1.00 \\
\hline & $(N)$ & 16 & 6 & 6 & 4 & 6 \\
\hline \multirow[t]{5}{*}{ Est-1 } & A & 0.06 & 0.00 & 0.00 & 0.00 & 0.00 \\
\hline & $\mathrm{B}$ & 0.69 & 0.83 & 0.67 & 0.00 & 0.00 \\
\hline & C & 0.25 & 0.17 & 0.33 & 1.00 & 0.00 \\
\hline & $\mathrm{D}$ & 0.00 & 0.00 & 0.00 & 0.00 & 1.00 \\
\hline & $(\mathrm{N})$ & 16 & 6 & 6 & 4 & 6 \\
\hline \multirow[t]{3}{*}{ Est-2 } & A & 1.00 & 1.00 & 0.00 & 1.00 & 0.00 \\
\hline & B & 0.00 & 0.00 & 1.00 & 0.00 & 1.00 \\
\hline & $(\mathrm{N})$ & 16 & 6 & 6 & 4 & 4 \\
\hline \multirow[t]{3}{*}{ Est-3 } & A & 0.00 & 0.00 & 0.00 & 0.25 & 0.00 \\
\hline & $\mathrm{B}$ & 1.00 & 1.00 & 1.00 & 0.75 & 1.00 \\
\hline & $(\mathrm{N})$ & 16 & 4 & 6 & 4 & 4 \\
\hline \multirow[t]{2}{*}{ Est-4 } & A & 1.00 & 1.00 & 1.00 & 1.00 & 1.00 \\
\hline & $(\mathrm{N})$ & 16 & 6 & 6 & 2 & 4 \\
\hline \multirow[t]{5}{*}{ Est-5 } & A & 0.00 & 0.00 & 0.00 & 0.25 & 0.25 \\
\hline & $\mathrm{B}$ & 0.00 & 0.17 & 0.00 & 0.25 & 0.75 \\
\hline & $\mathrm{C}$ & 0.75 & 0.50 & 0.00 & 0.00 & 0.00 \\
\hline & $\mathrm{D}$ & 0.25 & 0.33 & 1.00 & 0.50 & 0.00 \\
\hline & $(\mathrm{N})$ & 16 & 6 & 6 & 4 & 4 \\
\hline \multirow[t]{3}{*}{ Est- 6} & A & 0.00 & 0.00 & 1.00 & 0.75 & 0.25 \\
\hline & B & 1.00 & 1.00 & 0.00 & 0.25 & 0.75 \\
\hline & $(\mathrm{N})$ & 16 & 6 & 4 & 4 & 4 \\
\hline \multirow[t]{3}{*}{$H k$} & A & 1.00 & 1.00 & 0.00 & 0.00 & 1.00 \\
\hline & B & 0.00 & 0.00 & 1.00 & 1.00 & 0.00 \\
\hline & $(\mathrm{N})$ & 16 & 4 & 6 & 4 & 6 \\
\hline \multirow[t]{3}{*}{ Pep } & A & 0.81 & 1.00 & 1.00 & 1.00 & 1.00 \\
\hline & $\mathrm{B}$ & 0.19 & 0.00 & 0.00 & 0.00 & 0.00 \\
\hline & $(\mathrm{N})$ & 16 & 6 & 6 & 2 & 6 \\
\hline \multirow[t]{6}{*}{$P g i$} & $A$ & 0.00 & 0.50 & 0.00 & 0.00 & 0.00 \\
\hline & B & 0.00 & 0.50 & 0.00 & 0.00 & 0.00 \\
\hline & C & 0.00 & 0.00 & 0.00 & 0.00 & 1.00 \\
\hline & D & 1.00 & 0.00 & 0.00 & 0.50 & 0.00 \\
\hline & $E$ & 0.00 & 0.00 & 1.00 & 0.50 & 0.00 \\
\hline & $(\mathrm{N})$ & 10 & 4 & 6 & 4 & 6 \\
\hline
\end{tabular}

Table 3. Unbiased genetic identities (Nei 1978, below the diagonal) and distances (above the diagonal) for parwise comparisons between 4 morphs (A to D) of Plakina trilopha and $P$. monolopha from the Western Mediterranean.

\begin{tabular}{|lccccc|}
\hline Morph & A & B & C & D & P. monolopha \\
\hline A & - & 0.19 & 0.71 & 0.31 & 0.41 \\
B & 0.83 & - & 0.62 & 0.50 & 0.49 \\
C & 0.49 & 0.54 & - & 0.24 & 1.05 \\
D & 0.73 & 0.61 & 0.79 & - & 0.54 \\
$P$ monolopha & 0.66 & 0.61 & 0.35 & 0.58 & - \\
\hline
\end{tabular}

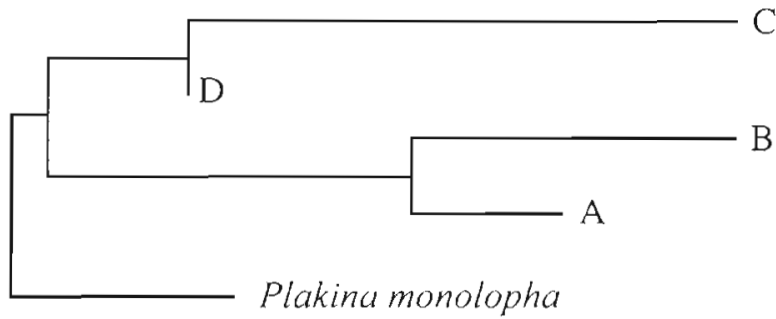

Fig. 1. Plakina trilopha. Neighbor-jouning tree (Saitou \& Nei 1987) based on unbiased genetic distances for the 4 morphotypes. $P$. monolopha was used as an outgroup 
Thus morphotypes A, C and D cannot be considered strictly sympatric, at least until more data is available on their distribution and larval behavior.

One approach to the delimitation of species boundaries is to reduce overall levels of genetic divergence between populations or species to a single value, using any of various published statistical indices of genetic similarity, identity or distance (see e.g. Thorpe 1979, 1982, Nei 1987). The most commonly used measure is the genetic identity (I) of Nei (1978), which ranges from 1 (populations identical) to 0 (total dissimilarity). As mentioned above, reviews of levels of genetic divergence observed between various populations and species over a wide range of phyla (Thorpe 1982, 1983, Nei 1987) suggest that conspecific populations generally have $I$-values above approximately 0.90 and rarely below 0.85 , whilst identity levels between congeneric species can be expected to range from about 0.35 to 0.85 , and species from different but confamilial genera usually show $I$-values below 0.40 . The $I$-values for all possible pairwise combinations for the 4 morphotypes studied ranged from 0.49 to 0.83 (Table 3), and are therefore placed well within the range expected of congeneric species, indicating that the 4 morphotypes are very unlikely to be conspecific.

A feature of Nei's $I$ is that sampling errors for estimates of divergence between species are little affected by the numbers of individuals used and depend almost entirely on the number of loci analyzed (Nei \& Roychoudhury 1974, Thorpe 1979). For the estimation of divergence between species, even sample sizes as small as 1 or 2 individuals will give fairly robust estimates of $I$ (Nei 1978, Gorman \& Renzi 1979, Thorpe 1982). Thus low $I$-values, together with the presence of diagnostic loci for each morphotype, provide evidence of the specific status of each of the 4 morphotypes studied.

A remaining problem is to establish which, if any, of the 4 morphotypes studied here is the original Plakina trilopha Schulze. There is no holotype available for this species, but the description and drawings of Schulze (1880) are complete enough to associate the original $P$. trilopha from Naples with the white spreading morphotype which we have called B. Complete descriptions and diagnosis of $P$. trilopha and the 3 new species discovered in this study will be published elsewhere.

As mentioned above, among the problems in defining a sponge species are the reduced number of useful morphological characters, the morphological plasticity and polymorphism found in many species, as well as the classical difficulty in conducting breeding experiments in sponges. Allozyme electrophoresis can set the limits of gene flow between populations, allowing estimation of morphological variation within and between species, and may thus help finding diagnostic criteria for species determinations. In a similar study made with the closely related genus Oscarella (BouryEsnault et al. 1992), it was shown that colour was a variable character in both $O$. lobularis and $O$. tuberculata, while consistency and cytological features were fixed for each species and therefore were good diagnostic features. Consistency, however, is difficult to define objectively, and cytological characters seemed to be more reliable in this case. The study of Mediterranean Clathrina species by Solé-Cava et al. (1991a) also concerned taxonomic problems essentially similar to those in Plakina.

In Mediterranean Plakina, external morphology, habitat and spiculation showed only slight variation within each species (as identified from the allozyme data) but were consistently different between species (even if only slightly; see Table 1) and, therefore, would serve as diagnostic features. Thus, morphotype A can be characterized by its yellow colour, associated with lobate, large spreading shape, large variation in spicule size, large amount of malformations and spined spicules, and the pattern of ramification of its lophocalthrops. Morphotypes A and B share the spreading lobate shape and the same spicule categories, but the latter is distinguished by its white colour, ramification pattern of lophocalthrops, and lesser percentage of malformations and spined spicules, even where the 2 species are sympatric. The other 2 species share a small, delicate discoidal shape fixed on the substrate by thin filaments. They can be distinguished morphologically by slight differences in spicule shape [morphotype $C$ spicules are more regular, smooth, and show greater relative thickness (width:length ratio) than those of D], and ecologically since $\mathrm{C}$ occurs in caves and D apparently does not.

It is of note that the 4 Mediterranean Plakina studied here are almost or wholly indistinguishable on the basis of conventional spicule characters, which are the classical criteria used in the systematics of the genus and many other sponge genera. Unsuspected interspecific variations in the degree of spination and malformations, relative thickness and the pattern of ramification of lophocalthrops appear to be more useful characters for the discrimination of sibling species in Plakina. Scanning electron micrographs (author's unpubl. results) suggest that the precise shape and pattern of ramification of each type of lophate spicules vary (although subtly) between species, but not within species, and, hence, are possibly characters of particular value for discriminating sibling species in Plakina. The presence or absence of a particular spicule category as a diagnostic character may lead to taxonomic errors in this group, because there may be wide differences in the abundance of each spicule category 
within any one individual. It is thus easy to fail to find spicular categories which are actually merely rare (e.g. tetralophose calthrops) and cannot be found in all individuals of a population. Moreover, as such characters are apparently not fixed for all individuals of a species, they should not be used as diagnostic traits to distinguish phylogenetic species (Davis \& Nixon 1992). On the other hand, the relative abundance of a common spicule category may be used as a clue to distinguish between species: morphotypes $\mathrm{A}$ and $\mathrm{B}$ as compared with $C$ and $D$ have their lophate spicules consistently dominated by trilophose and dilophose calthrops, respectively.

Plakina trilopha sensu stricto (morphotype B) is reported to be widely distributed in the Mediterranean and other seas, and is found in sciaphilic habitats in sheltered and exposed rocky shores from 1 to about $1000 \mathrm{~m}$ depth. The other 3 species in the complex have so far been found only in certain caves and vertical walls around Marseilles, and in only 1 site each. These caves form a very special habitat, with high diversity of sponges and other invertebrates, and a strong reduction in light, nutrient supply and water circulation (Harmelin et al. 1985, Boury-Esnault et al. 1993). The caves were immersed about 8000 yr ago, and may function as islands, with isolated populations. It could be hypothesized that evolution in this group has occurred by independent colonization events in the different caves of the region, followed by reproductive isolation of the subpopulations due to the restricted water circulation in the caves, associated with the low dispersal capabilities of most sponge larvae (i.e. micro-allopatric speciation). However, it is unlikely that the level of genetic differentiation observed could have evolved in the short time available since immersion of the caves (Nei 1987, Thorpe 1989). Hence, like other sponges such as the hexactinellid Oopsacas minuta and the cladorhizid Asbestopluma sp. (Boury-Esnault et al. 1993, Vacelet \& Boury-Esnault 1995), these species presumably evolved away from the caves which they now occupy, possibly in the deeper parts of the Mediterranean, and may have come to colonize shallower depths brought along the Cassidaigne Canyon by the strong upwelling currents frequent in the area.

Acknowledgements. We thank $J$ Vacelet for taxonomic advice, C. Jalong for technical assistance and T. Norton and F. Blanc for provision of facilities. This work was supported by Conselho Nacional de Desenvolvimento Científico e Tecnológico (CNPq), Education Ministry, Brazil, Université de la Méditerranée, CNRS URA-41, France, and CEE MAST2-CT91-004 programs.

\section{LITERATURE CITED}

Avise JC (1994) Molecular markers, natural history and evolution. Chapman and Hall, London

Ayala FJ (1983) Enzymes as taxonomic characters. In: Oxford GS, Rollinson D (eds) Protein polymorphism: adaptive and taxonomic significance. Academic Press, London, p 3-26

Bavestrello G, Sarà M (1992) Morphological and genetic differences in ecologically distinct populations of Petrosia (Porifera, Demospongiae). Biol J Linn Soc 47:49-60

Boury-Esnault N, Harmelin JG, Vacelet J (1993) Les abysses méditerranéennes à vingt mètres de profondeur? La Recherche 24:849-851

Boury-Esnault N, Solé-Cava AM, Thorpe JP (1992) Genetic and cytological divergence between colour morphs of the Mediterranean sponge Oscarella lobulans (Schmidt) (Porifera, Demospongiae, Oscarellidae). J Nat Hist 26: $271-284$

Davis JI, Nixon KC (1992) Populations, genetic variation, and the delimitation of phylogenetic species. Syst Biol 41: $421-435$

Diaz MC, Van Soest RWM (1994) The Plakinidae: a systematic review. In: Van soest RWMi, van hempen TMG, Braekman JC (eds) Sponges in time and space. Balkema, Rotterdam, p 93-109

Gorman GC, Renzi J (1979) Genetic distance and heterozygosity estimates in electrophoretic studies: effects of sample size. Copela 1979:242-249

Harmelin JG, Vacelet J, Vasseur P (1985) Les grottes sousmarines obscures: un milieu extrême et un remarquable biotope refuge. Téthys 11:214-229

Harris $H$, Hopkinson DA (1978) Handbook of enzyme electrophoresis in human genetics. North Holland, Amsterdam

Klautau M, Solé-Cava AM, Borojevic R (1994) Biochemical systematics of sibling sympatric species of Clathrina (Porifera, Calcarea). Biochem Syst Ecol 22:367-375

Kumar S, Tamura K, Nei M (1993) MEGA: molecular evolutionary genetics analysis, version 1.0. Pennsylvania State University, University Park

Laubenfels MW de (1951) The sponges of the Island of Hawaii. Pacif Sci 5:251-272

Lévi C (1973) Systématique de la classe des Demospongiaria (démosponges). In: Grassé PP (ed) Traité de zoologie, Tome 3, Spongiaires. Masson, Paris, p 577-631

Lévi C, Lévi P (1989) Spongiaires (Musorstom 1 \& 2). Mém Mus Natl Hist Nat 143:25-103

Nei M (1978) Estimation of average heterozygosity and genetic distance from a small number of individuals Genetics 89:583-590

Nel M (1987) Molecular evolutionary genetics. Columbia University Press, New York

Nei M, Roychoudhury AK (1974) Sampling variances of het erozgosity and genetic distances. Genetics 76:379-390

Richardson BJ, Baverstock PR, Adams M (1986) Allozyme electrophoresis. Academic Press, Sydney

Ryman N, Utter F (1987) Population genetics and fishery management. University of Washington Press, Seattle

Saitou N, Nei M (1987) The neighbor-joining method. A new method for reconstructing phylogenetic trees. Mol Biol Evol 4:298-311

Schulze FE (1880) Untersuchungen über den Bau und die Entwicklung der Spongien. Die Plakunıden. Z Wiss Zool 34:407-451

Solé-Cava AM, Boury-Esnault N, Vacelet J, Thorpe JP (1992) Biochemical genetic divergence and systematics in sponges of the genera Corticium and Oscarella (Demo. 
spongiae: Homoscleromorphal in the Mediterranean Sea. Mar Biol 113:299-304

Solé-Cava AM, Klautau M, Boury-Esnault N, Borojevic R Thorpe JP (1991a) Genetic evidence for cryptic speciation in allopatric populations of two cosmopolitan species of the calcareous sponge genus Clathrina. Mar Biol 111 $381-386$

Solé-Cava AM, Thorpe JP (1986) Genetic differentiation between morphotypes of the marine sponge Suberites ficus (Demospongiae: Hadromerida). Mar Biol 93:247-253

Solé-Cava AM, Thorpe JP (1994) Evolutionary genetics of marine sponges. In: Van Soest RWM, Van Kempen TMG, Braekman JC (eds) Sponges in time and space. Balkema, Rotterdam, p 55-63

Solé-Cava AM, Thorpe JP, Manconi R (1991b) A new species of Mediterranean Axinella (Porifera-Demospongiae) detected by isozyme electrophoresis. In: Reitner J, Keupp $\mathrm{H}$ (eds) Fossil and recent sponges. Springer Verlag, Berlin, p 313-321

Swofford DL, Selander RB (1981) BIOSYS-1 - a FORTRAN program for the comprehensive analysis of electrophoretic data in population genetics and systematics. J Hered 72 : $281-283$

Thomas PA (1970) Studies on Indian sponges - VII. Two new records and a new species of the genus Plakina Schulze (Carnosida: Halinidae) from the Indian region. J Mar Biol Ass India 12:51-56

Thorpe JP (1979) Enzyme variation and taxonomy: the estimation of sampling errors in measurements of interspecific genetic similarity. Biol J Linn Soc 11:369-386

This article was submitted to the editor
Thorpe JP (1982) The molecular clock hypothesis: biochemical evolution, genetic differentiation and systematics. A Rev Ecol Syst 13:139-168

Thorpe JP (1983) Enzyme variation, genetic distance and evolutionary divergence in relation to levels of taxonomic separation. ln: Oxford GS, Rollinson D (eds) Protein polymorphism: adaptive and taxonomic significance. Academic Press, London, p 131-152

Thorpe JP (1989) Possible effects of interprotein variation in mean rate of amino acid substitution on the relationship of genetic distance with time since evolutionary divergence. Biol J Linn Soc 37:335-344

Thorpe JP, Solé-Cava AM (1994) The use of allozyme electrophoresis in invertebrate systematics. Zool Scr 23: $3-18$

Topsent E (1895) Etude monographique des spongiaires de France II. Carnosa. Arch Zool Exp Gén 3:493-590

Topsent E (1917) Spongiaires. In: Deuxième expédition Antarctique française (1908-1910) commandée par le Dr. Jean Charcot. Masson, Paris

Uriz MJ, Bibiloni MA (1984) Esponjas Homoscleroforidas (Demospongiae) del litoral Catalan. Misc Zool 8:7-12

Vacelet J, Vasseur P (1971) Eponges des récifs coralliens de Tuléar (Madagascar). Téthys suppl 1:51-126

Vacelet J, Boury-Esnault N (1995) Carnivorous sponges. Nature 373:333-335

Van Soest RWM, Van Kempen TMG, Braekman JC (1994) Sponges in time and space. Balkema, Rotterdam

Ward RD. Beardmore JA (1977) Protein variation in the plaice (Pleuronectes platessa). Genet Res 30:45-62

Manuscript first received: July 4, 1994

Revised version accepted: January 10, 1996 